BIOKEMISTRI 17(2):185-191 (Dec 2005)

Available online at http://www. bioline.org.br/bk.

Abstracted online at www.ajol.info/journals/biokem

Printed in Nigeria

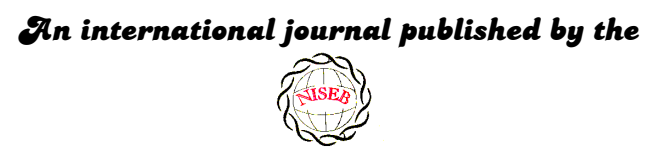

Tigerian \&ociety for \&ิxperimental \&iology

\title{
Activities of alkaline phosphatase, glutamate oxaloacetate transaminase and glutamate pyruvate transaminase in liver and serum of Trypanosoma brucei-infected rats treated with honey
}

\author{
Justine T. EKANEM* and Oluwatosin K. YUSUF
}

Trypanosomosis Research Unit, Department of Biochemistry, University of Ilorin, PMB 1515, Ilorin, Nigeria

Received 28 September 2005

MS/No BKM/2005/045, @ 2005 Nigerian Society for Experimental Biology. All rights reserved.

\begin{abstract}
Alkaline phosphatase, glutamate oxaloacetate transaminase and glutamate pyruvate transaminase activities were assessed in rats highly infected with federe strain of Trypanosoma brucei and treated with honey. Therapeutic effect of honey on parasitaemia was also assessed. Results show an extension in the life span of infected but treated rats from 12 days for control to 19 days for infected honey-treated rats. Parasitaemia was also effectively lowered. Alkaline phosphatase activity was increased in the serum but not significantly different in the liver. Glutamate oxaloacetate transaminase and glutamate pyruvate transaminase were also increased in the serum but there is decrease in glutamate pyruvate transaminase activity in the liver. There were no significant differences in glutamate oxaloacetate transaminase activity in the liver. Results suggest that, honey could be a potential agent in the management of African trypanosomosis. However, it leads to decrease in glutamate pyruvate transaminase activity in the liver suggesting liver damage. Increase in glutamate oxaloacetate transaminase and alkaline phosphatase activities in the serum also suggest possible damage to other organs where these maybe abundant.
\end{abstract}

Key words: Honey, Alkaline phosphatase, Transaminase, Sleeping sickness

*Author to whom all correspondence should be addressed.

E-mail: jtekanem@scientist.com, Tel: +234 8033880310 


\section{INTRODUCTION}

In the absence of treatment, trypanosomosis is often fatal in $\operatorname{man}^{1}$. The mechanisms of pathogenicity and adverse reactions resulting from some drug treatments are only partially understood and remain a considerable challenge to scientists ${ }^{1}$. Trypanosomes with their antigenic variations have topological preferences within host and particular organs ${ }^{2,3}$. The host defense mechanism is only partially specific and often out of phase with the progress of the disease $\mathrm{e}^{3}$. Indications are that all organs are invaded by trypanosomes with the central nervous system involvement leading to coma and death ${ }^{1,3}$.

Despite many investigations, the mechanism by which Trypanosoma brucei and other trypanosomes induce pathogenicity including anaemia is only partially understood as different combinations of host, parasite and perhaps other factors make the pattern of pathogenesis quite variable $^{3}$.

Hepatomegaly occurs in $T$. brucei infection ${ }^{4}$ and is also reported to be directly related to the severity of anaemia and levels of parasitaemia ${ }^{5}$. Arowolo et $\mathrm{al}^{6}$ described high levels of serum Alkaline phosphatase among other parameters in $T$. brucei-infected rabbits and associated these with a state of depressed liver function.

Honey is a natural product that is widely available in different parts of the world ${ }^{7-11}$ and is readily obtained from natural or cultured bee colonies. It has been reported as having antimicrobial properties ${ }^{12}$ as well as therapeutic effects on internal and external ailments ${ }^{13-15}$.

In this report, we have assessed the trypanocidal properties of honey in relation to the activities of alkaline phosphatase, glutamate oxaloacetate transaminase and glutamate pyruvate transaminase in the liver and serum of T. bruceiinfected rats at high parasitaemia.

\section{MATERIALS AND METHODS}

\section{Experimental animals}

Male albino rats weighing approximately $270 \mathrm{~g}$ were obtained from the Animal holdings of the University of Ibadan, acclimatized for about 14 days and fed with animal feed obtained from
Bendel Feeds and Flour Mills Ltd, Ewu, Edo State, Nigeria and water was provided ad libitum

\section{Parasite Strain}

Federe strain of $T$. brucei was obtained from Veterinary \& Livestock Studies Department of the Nigerian Institute for Trypanosomiasis Research, Vom, Plateau State of Nigeria. The parasite was maintained by repeated passages into other rats. $0.5 \mathrm{ml}$ of parasite suspension in $0.9 \%$ saline solution was inoculated into the peritoneal cavity of uninfected rat. The suspension contained 3 or 4 trypanosomes per view at x100 magnification.

\section{Parasite Count}

Parasite count in infected rats was carried out on daily basis to monitor infection progress until the animals died. Parasitaemia was determined by counting the number of trypanosomes per view under the light microscope at $\times 100$ magnification from thin blood smear freshly obtained from the tip of the tail of infected rats.

\section{Honey}

Natural but pure honey was obtained from Bee Culturing Unit of the Faculty of Agriculture, University of Ilorin, Nigeria and used without additional processes.

\section{Tissue Preparation}

The rats were anaesthetized in a jar containing chloroform. They were thereafter cleared of fur at the neck area to expose the jugular vein and blood collected are allow to coagulate and centrifuge at $1000 \mathrm{rpm}$ for 10 minutes to get clear serum. Livers removed were homogenized in ice-cold $0.25 \mathrm{M}$ sucrose solution $(1: 5 \mathrm{w} / \mathrm{v})$ and centrifuged at $1000 \mathrm{rpm}$ for $10 \mathrm{mins}$. The filtrate were stored for analysis.

\section{Enzyme and Protein determinations}

Assay kits for glutamate oxaloacetate and glutamate pyruvate transaminases were obtained from Randox laboratoriesLtd, United Kingdom and that for alkaline phosphatase was obtained from Teco Ltd, United Kingdom. Protein concentrations were determined using biuret method as described by Plummer ${ }^{16}$. Alkaline phosphatase (E.C 3.1.3.1) was assayed as described by Wright et $a l^{17}$ using 
phenolphthalein monophosphate as substrate $^{18}$. Glutamate oxaloacetate and glutamate pyruvate transaminases activities were assayed by monitoring the concentration of hydrazone formed from 2,4-dinitrophenylhydrazone as described by Mohun and $\operatorname{Cook}^{19}$.

\section{Experimental Design}

The experiments were carried out in two stages. Each group of experiments in the two stages contained five rats. In the first stage, infected rats were administered $3 \mathrm{mg} / \mathrm{Kg}$ body weight of pure honey on daily basis from the day parasite was first sighted in the blood until the rats died. The control rats were infected but not treated. In the second stage, serum and liver were obtained from late stage infected rats (Day 11 postinfection) and late stage infected but honeytreated rats as well as from normal uninfected honey treated rats. The control group for this stage was normal uninfected rats that received no honey treatment under the same experimental conditions. Data were statistically analyzed and difference compared using the Student's ' $t$ ' test $^{20}$.

\section{RESULTS}

\section{Therapeutic properties of honey}

Fig 1 shows the result of infected rats treated with honey at $3.0 \mathrm{mg} / \mathrm{kg}$ body weight. The treatment extended the life span of infected rats from 12 days of control (infected non-treated) to 19 days post infection for infected honey treated rats. The parasitaemia was also effectively kept low throughout the treatment.

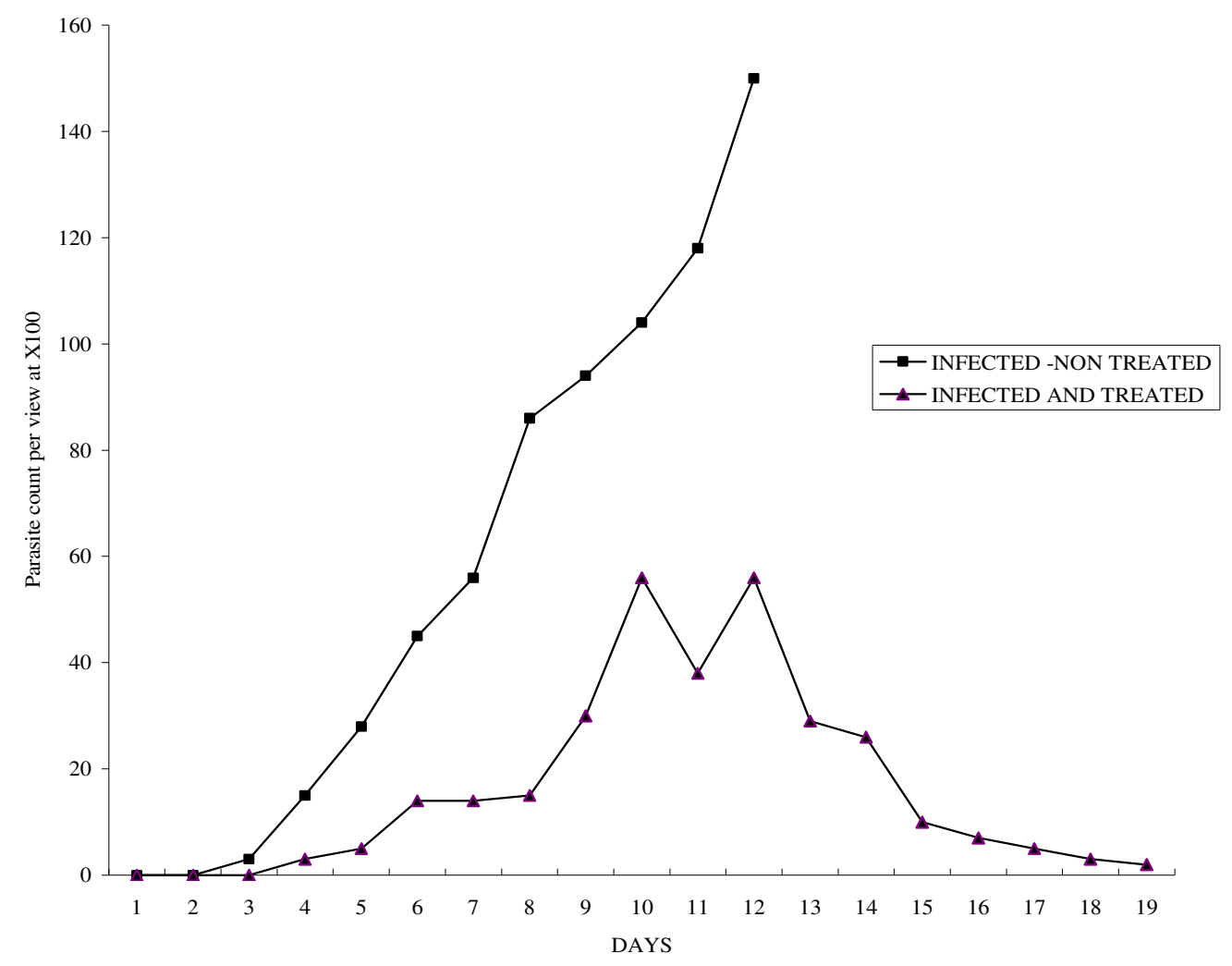

Fig. 1: Parasite count in T. brucei-infected rats. Rats treated with honey were inoculated at $3 \mathrm{mg} / \mathrm{Kg}$ body weight once daily until the animals died. Each point is an average count from five infected rats. 


\section{Protein concentrations}

There was significant decrease in serum protein concentration in the infected non-treated, normal honey-treated, and infected honey-treated rats in comparison with the uninfected (normal) rats which did not receive any treatment. (Table 1).The serum protein concentration in infected honey-treated rats was however significantly higher when compared with infected nontreated. In contrast, the liver protein concentrations showed significant increases when compared with that of the normal rats. Significant increase was also observed when liver protein concentration in infected honeytreated rats were compared with infected nontreated as well as with normal honey-treated rats (Table 1)

Table 1: Levels of protein concentration in $T$. brucei infected rats

\begin{tabular}{|c|c|c|}
\hline \multirow{2}{*}{$\begin{array}{l}\text { Rat } \\
\text { groupings }\end{array}$} & \multicolumn{2}{|c|}{$\begin{array}{c}\text { Protein concentration } \\
(\mathrm{mg} / \mathrm{ml})\end{array}$} \\
\hline & Serum & Liver \\
\hline $\begin{array}{l}\text { Uninfected } \\
\text { (normal) }\end{array}$ & $2.00 \pm 0.20$ & $0.400 \pm 0.00$ \\
\hline $\begin{array}{l}\text { Infected } \\
\text { non-treated }\end{array}$ & $1.07 \pm 0.30^{\mathrm{a}}$ & $0.467 \pm 0.06^{\mathrm{a}}$ \\
\hline $\begin{array}{l}\text { Normal } \\
\text { honey-treated }\end{array}$ & $1.25 \pm 0.40^{\mathrm{a}}$ & $0.488 \pm 0.05^{\mathrm{a}}$ \\
\hline $\begin{array}{l}\text { Infected } \\
\text { honey-treated }\end{array}$ & $1.15 \pm 0.05^{\mathrm{ab}}$ & $0.700 \pm 0.10^{\mathrm{abc}}$ \\
\hline
\end{tabular}

\section{Alkaline phosphatase activities}

Result of serum and liver alkaline phosphatase assays is shown in Table 2. At $\mathrm{p}<0.05$, serum alkaline phosphatase activities were significantly higher in infected non-treated, normal honeytreated and infected honey-treated rats when compared with uninfected normal rats. The infected honey -treated rats also showed significantly high alkaline phosphatase activity in serum when compared with the serum activity in infected non-treated rats. There were no significant differences in the liver enzyme activities
Table 2:Specific Activities of Alkaline phosphatase

\begin{tabular}{|l|c|c|}
\hline \multirow{2}{*}{$\begin{array}{l}\text { Rat } \\
\text { groupings }\end{array}$} & \multicolumn{2}{|c|}{$\begin{array}{c}\text { Enzyme activity } \\
\text { (IU/L/mg protein) }\end{array}$} \\
\cline { 2 - 3 } & Serum & Liver \\
\hline $\begin{array}{l}\text { Uninfected } \\
\text { (normal) }\end{array}$ & $31.95 \pm 2.00$ & $32.50 \pm 15.00$ \\
\hline $\begin{array}{l}\text { Infected } \\
\text { non-treated }\end{array}$ & $55.63 \pm 4.40^{\mathrm{a}}$ & $16.10 \pm 6.80$ \\
\hline $\begin{array}{l}\text { Normal } \\
\text { honey-treated }\end{array}$ & $61.81 \pm 12.10^{\mathrm{a}}$ & $20.13 \pm 6.10$ \\
\hline $\begin{array}{l}\text { Infected } \\
\text { honey-treated }\end{array}$ & $65.82 \pm 2.20^{\mathrm{ab}}$ & $28.96 \pm 7.30$ \\
\hline
\end{tabular}

Each specific enzyme activity is an average of five determinations \pm SEM. Values are significantly different in comparison with ${ }^{a}$ uninfected (normal) rats and ${ }^{b}$ infected non-treated rats at $p<0.05$.

\section{Glutamate oxaloacetate transaminase activities}

The serum glutamate oxaloacetate transaminase activities in the infected non-treated and normal honey-treated rats were comparable with that in the uninfected normal rats (Table 3) .The serum enzyme activity in the infected honey-treated rats was however significantly higher than those of the uninfected normal rats, infected nontreated and normal honey-treated rats (Table 3). The liver glutamate oxaloacetate transaminase activities in the infected non-treated, normal honey treated and infected honey-treated were all significantly lower than that of the uninfected normal rats. The activity in infected honeytreated rats were comparable with those of the infected non -treated and normal honey-treated rats (Table 3)

Table 3: Specific Activities of glutamate oxaloacetate transaminase

\begin{tabular}{|l|l|l|}
\hline \multirow{2}{*}{ Rat groupings } & \multicolumn{2}{|c|}{$\begin{array}{c}\text { Enzyme activity } \\
\text { (IU/L/mg protein) }\end{array}$} \\
\cline { 2 - 3 } & Serum & Liver \\
\hline $\begin{array}{l}\text { Uninfected } \\
\text { (normal) }\end{array}$ & $18.31 \pm 4.40$ & $130.00 \pm 17.50$ \\
\hline $\begin{array}{l}\text { Infected } \\
\text { non-treated }\end{array}$ & $27.35 \pm 5.40$ & $64.43 \pm 25.50^{\mathrm{a}}$ \\
\hline $\begin{array}{l}\text { Normal honey- } \\
\text { treated }\end{array}$ & $25.48 \pm 7.20$ & $64.35 \pm 15.40^{\mathrm{a}}$ \\
\hline $\begin{array}{l}\text { Infected } \\
\text { honey-treated }\end{array}$ & $65.70 \pm 8.50^{\mathrm{abc}}$ & $70.21 \pm 1.50^{\mathrm{a}}$ \\
\hline
\end{tabular}

Each specific enzyme activity is an average of five determinations \pm SEM. Values are significantly different in comparison with aninfected (normal) rats, ${ }^{b}$ infected nontreated rats and ${ }^{c}$ normal honey treated rats at $p<0.05$. 


\section{Glutamate pyruvate transaminase activities}

The results of the glutamate pyruvate transaminase activities in the serum and liver are presented in Table 4. The serum enzyme activities in the infected non-treated and infected honey treated rats are significantly higher than that of the uninfected normal rats. The activity in infected honey-treated rats is also significantly higher than those of infected non-treated and normal honey-treated rats. The liver glutamate pyruvate transaminase activity in the infected honey treated rats was significantly lower than those of the normal, infected non-infected and normal honey-treated rats which were themselves comparable with each other.

Table 4: Specific Activities of glutamate pyruvate transaminase

\begin{tabular}{|l|c|c|}
\hline \multirow{2}{*}{$\begin{array}{l}\text { Rat } \\
\text { groupings }\end{array}$} & \multicolumn{2}{|c|}{$\begin{array}{c}\text { Enzyme activity } \\
\text { (IU/L/mg protein) }\end{array}$} \\
\cline { 2 - 3 } & Serum & Liver \\
\hline $\begin{array}{l}\text { Uninfected } \\
\text { (normal) }\end{array}$ & $20.39 \pm 1.30$ & $90.00 \pm 27.50$ \\
\hline $\begin{array}{l}\text { Infected } \\
\text { non-treated }\end{array}$ & $52.24 \pm 11.10^{\mathrm{a}}$ & $86.67 \pm 3.00$ \\
\hline $\begin{array}{l}\text { Normal } \\
\text { honey-treated }\end{array}$ & $32.58 \pm 12.90$ & $80.43 \pm 4.50$ \\
\hline $\begin{array}{l}\text { Infected } \\
\text { honey-treated }\end{array}$ & $65.80 \pm 3.30^{\mathrm{abc}}$ & $19.59 \pm 2.90^{\mathrm{abc}}$ \\
\hline
\end{tabular}

Each specific enzyme activity is an average of five determinations \pm SEM. Values are significantly different in comparison with ${ }^{a}$ uninfected (normal) rats, ${ }^{b}$ infected non-treated rats and ${ }^{c}$ normal honey treated rats at $p<0.05$.

\section{DISCUSSION}

We present here for the first time studies utilizing the therapeutic properties of honey as a possible agent for the management of African sleeping sickness. Administration of honey to infected rats was able to reduce the parasitaemia and extend the lifespan of infected rats compared to infected non-treated rats (Fig. 1). It is well documented that honey has antimicrobial and therapeutic properties ${ }^{12-15}$. The composition and physicochemical properties of honey may be responsible for its therapeutic properties, ${ }^{9,10,15}$. Honey is known to contain some level of hydrogen peroxide ${ }^{21}$, a factor which may not be unconnected with its ability to maintain low parasitaemia in trypanosome-infected rats (Fig.
1) as trypanosomes do not have efficient mechanism for metabolizing hydrogen peroxide $^{22}$. The quality of carbohydrate composition $^{9,10}$ may also play a role because the nutritional requirement of $T$. brucei is specifically glucose ${ }^{23}$ which may largely be replaced by other forms of sugar depending on the source of honey.

Alkaline phosphatase is distributed in almost every tissue of the body especially those involved in active transport mechanism such as kidney, intestinal mucosa and mammary gland $^{24,25}$. Serum alkaline phosphatase levels are of interest in the diagnosis of hepatobillary disorder and bone disease ${ }^{25}$. The significant increase in liver protein concentration of infected honey-treated rats (Table 1) compared to those of uninfected normal, infected nontreated and normal honey-treated rats may be due to activation of some proteins or enzymes. The significant increase may have been caused by the combined presence of parasite and honey. It is not immediately known why there was a significant decrease in serum protein concentration but liver damage, impaired intake of protein and toxic destruction of the protein may be responsible for this ${ }^{25,29}$

The significant increase in serum alkaline phosphatase activity of infected honey-treated rats when compared with infected non-treated and normal honey-treated rats with no concomitant changes in enzyme activities in liver (Table 2) implies that there is increased production of the enzyme from organs other than liver with leakage into the serum. Elevation of serum alkaline phosphatase activity not involving the liver or bone is sometimes attributed to congestive heart failure and abdominal bacterial infections ${ }^{24,26}$.

Glutamate oxaloacetate and Glutamate pyruvate transaminases are normally localized within the cells of the liver, heart, kidney, muscles and other organs. They are well known transaminases that play important roles in amino acids metabolism and providing necessary intermediates for gluconeogenesis. They have also been implicated as major enzymes in assessing and monitoring liver cytolysis ${ }^{27}$. Their 
elevation in the serum gives information on organ dysfunction ${ }^{27-29}$. The significant increase in the serum of both enzyme activities in infected honey-treated rats compared to infected non-treated, normal honey-treated and uninfected normal rats gives an indication of cytotoxicity to organ. However, decreases in liver glutamate oxaloacetate transaminase activity of infected honey-treated compare to infected non-treated, normal honey-treated and uninfected normal rats suggest the leakage of the enzyme into the serum from liver. Glutamate pyruvate transaminase is more liver specific ${ }^{28}$ than glutamate oxaloacetate transaminase. Significant decrease in glutamate pyruvate transaminase in the liver is due to liver dysfunction.

In conclusion, we suggest that administration of honey to trypanosome-infected individuals may be a possible agent for the management of African trypanosomosis. We however caution that the use of honey for therapeutic purposes may also have some unexpected damaging effects on the organs of infected mammals.

\section{REFERENCES}

1.Pentreath V. W. and Kennedy G. E. (2004) Pathogenesis of human African trypanosomiasis. In The Trypanosomiasis (eds. I. Maudlin, P. H. Holmes and Miles) CABI Publishing, pp 283-301

2.Poltera, A. A. (1985) Pathology of human African trypanosomiasis with reference to experimental African trypanosomiasis and infections of the central nervous system. Brit. Med. Bull. 41:169-174

3.Sternberg, J. M. (2004) Human African trypanosomiasis: clinical presentation and immune response. Parasite Immunol. 26:469-476

4.Amole, B. O., Clarrkson, A. B. and Shear, H. L. (1982) Pathogenesis of anaemia in Trypanosoma brucei infected mice. Infect. Immun. 36:1060-1068

5.Anosa, V. O. (1988) Haematological and biochemical changes in human and animal trypanosomiasis. Revue Elev. Med. Vet. Pays Trop. 42:65-78

6.Arowolo, R. O. A., Elhazzan, E. O. and Amure, B. O. (1988) Assessing hepatic dysfunctions in rabbits experimentally infected with Trypanosoma brucei. Revue Elev. Med. Vet. Pays Trop. 41:277-281

7.Terrab, A., González, A. G., Díez, M. J. and Heredia, F. J. (2003) Mineral content and electrical conductivity of the honeys produced in Northwest Morocco and their contribution to the characterisation of unifloral honeys. J. Sci. Food Agric. 83:637-643

8. Yao, L., Bhandari, B. R., Datta, N., Singanusong, R. and D'Arcy, B. R. (2003) Crystallisation and moisture sorption properties of selected Australian unifloral honeys. J. Sci. Food Agric. 83: 884-888

9.Bonvehí, J. S., Manzanares, A. B. and Vilar, J. M. S. (2004) Quality evaluation of broom honey (Spartocytisus supranubius L) produced in Tenerife (The Canary Islands). J. Sci. Food Agric. 84:1097-1104

10. Sanz, M.L., Gonza' lez, M., de Lorenzo, C., Sanz1, J. and Mart'inez-Castro. I. (2004) Carbohydrate composition and physicochemical properties of artisanal honeys from Madrid (Spain): occurrence of Echium sp honey. J Sci Food Agric 84:1577-1584

11. Malacalza, N. H., Caccavari, M. A., Fagúndez, G. and Lupano, C. E. (2005) Unifloral honeys of the province of Buenos Aires, Argentine. J. Sci. Food Agric. 85:1389-1396

12. Adebolu, T.T. (2005) Effect of natural honey on local isolates of diarrhea-causing bacteria in southwestern Nigeria. Afr. J. Biotech. 4:1172-1174

13. Greenwood D. (1993) Honey for superficial wounds and ulcers. Lancet 341:90-91

14. Okeniyi, J. A. O. (2005) Comparison of healing of incised abscess wounds with honey \&eusol dressing. J. Alter. Compl. Med. 11:511-513

15. Orsolic, N., Terzic, S., Scaronver, L. and Basic, I. (2005) Honey-bee products in prevention and/or therapy of murine 
transplantable tumours. J. Sci. Food Agric. 85:363-370

16. Plummer T. (1978) An introduction to practical biochemistry ( $2^{\text {nd }}$ ed.) Mc GrawHILL, London.pp144-145

17. Wright, P. J., Leathwood, P.D and Plummer. D. T (1972) Enzymes in rat urine. Alkaline Phosphatase.Enzymologia 42:459-462.

18. Babson, A. L., Greeley, S. J., Coleman, C. M. and Philips, G. D. (1966) Phenolphthalein monophosphate as a substrate for serum alkaline phosphatase. Clin. Chem. 12:482-490

19. Mohun, A. F and Cook, L. J. (1957) Simple method of measuring serum levels of glutamate oxaloacetate \& glutamate pyruvate transaminases. J. Clin. Pathol. 10:394-399

20. Student, pseudo. (Gosset, W. S.) (1908) The error of a mean. Biometrika 6: 1-25

21. Phuapradit W and Saropala N. (1992) Topical application of honey in treatment of abdominal wound disruption. Aust $N Z$ J Obstet .Gynaecol. 32:381-4.

22. Schleker, T., Schmidt, A., Dirdjala, N., Vonken, F., Clayton, C. and KrauthSiegel, R. L. (2005) Substrate specificity, localization and essential role of the gluthathione pereoxidase-type tryparedoxin peroxidases in Trypanosoma brucei. J. Biol. Chem. 280:14385-14394

23. Besteiro, S., Barrett, M. P., Riviere, L. and Bringaud, F. (2005) Energy generation in insect stages of Trypanosoma brucei: metabolism in flux. Tends Parasitol. 21:185-191

24. Wright, P. J. and Plummer, D. T. (1974) The use of urinary enzyme measurements to detect renal damage caused by nephrotoxic compounds. Biochem Pharmacol. 23:65-73.

25. Kaplan, M.M (1972) Alkaline Phosphatase. Gastroenterology. 62:452-68

26. Tietz, N. W. (1987) Probable source of discrepancies in alkaline phosphate assays. Clin Chem. 33:625

27. Hanley, K. S. Schmidt, E. and Schmidt, FM (1986) Enzymes in Serum, their volume in diagnosis, pp 70-81. Charles Thomas, Springfield Illinois

28. Kochmar, J. F. and Moss, D. W. (1976) Fundamentals of Clinical Chemistry. N. W. Tietz (ed) p 604. W. B. Sanders and Company, Philadelphia PA

29. Baron, D. N. A (1973) Short textbook of chemical pathology ( $3^{\text {rd }}$ edition) English language and book society (ELBS), Hodder and Stoughton London. pp. 87. 